\title{
Life history traits of the invasive estuarine shrimp Palaemon macrodactylus (Caridea: Palaemonidae) in a marine environment (Mar del Plata, Argentina)
}

\author{
MARÍA GUADALUPE VÁZQUEZ, CLAUDIA C. BAS and EDUARDO D. SPIVAK \\ Instituto de Investigaciones Marinas y Costeras, Consejo Nacional de Investigaciones Científicas y Técnicas, \\ Departamento de Biología, Facultad de Ciencias Exactas y Naturales, Universidad Nacional de Mar del Plata, \\ Casilla de correos 1245, 7600 Mar del Plata, Buenos Aires, Argentina. E-mail mgvazque@mdp.edu.ar
}

\begin{abstract}
SUMMARY: The invasive oriental shrimp Palaemon macrodactylus has been extensively recorded around the world, mainly in estuarine zones. In this study, the life history of this species was studied in Mar del Plata harbour (Argentina), a fully marine area where a stable and dense population has been established. Growth, sex proportion, morphological relationships, size at maturity and reproductive cycle were analysed between March 2007 and March 2009. A total of 9 and 7 modal classes (M1-M9) were detected in the size frequency distributions of females and males, respectively. The modes of both sexes were the same until M4 but from M5 to M7 females were larger than males. The life span was about one year with a clear seasonal growth. Recruitment and reproductive periods were recorded from December to March and October to March, respectively. The total sex ratio was biased to females. Nevertheless, a clear predominance of males was observed in classes smaller than $5.25 \mathrm{~mm}$ carapace length (CL). Females reached maturity at a larger size in spring to early summer (October-January) than in late summer (February-March); the estimated sizes for $50 \%$ sexual maturity were $6.79 \mathrm{~mm}$ and $5.91 \mathrm{~mm}$ CL, respectively. The results showed great differences from a presumably native estuarine population (Japan), such as shorter life span, smaller maximum size and smaller size at maturity.
\end{abstract}

Keywords: life history, growth, intraspecific variability, invasive species, Caridea, reproduction.

RESUMEN: Características del Ciclo vital del camarón estuarino inVASOR Palaemon maCrodactylus (Caridea: PalaemoNidAe) En un Ambiente marino (Mar del Plata, Argentina). - El camarón oriental invasor Palaemon macrodactylus ha sido ampliamente documentado, principalmente en estuarios, alrededor del mundo. En este trabajo el ciclo de vida fue estudiado en el Puerto de Mar del Plata (Argentina), donde se registró una población estable y abundante en un ambiente netamente marino. Entre marzo de 2007 y marzo de 2009 se estudiaron: el crecimiento, la proporción de sexos, relaciones morfológicas, la talla de madurez y el ciclo reproductivo. A partir de las distribuciones de frecuencia de tallas se detectó un total de 7 y 9 clases modales (M1-M9) para machos y hembras respectivamente. Las modas de ambos sexos fueron iguales hasta la M4, mientras que en las M5-M7, las hembras fueron mayores. El tiempo de vida estimado fue de un año, con un crecimiento claramente estacional. El reclutamiento y el período reproductivo fueron registrados entre diciembre y marzo y entre octubre y marzo respectivamente. La relación de sexos fue sesgada hacia las hembras. Sin embargo, en las tallas menores a $5.25 \mathrm{~mm}$ de LC los machos fueron mayoría. Las hembras alcanzaron la madurez a una talla mayor en primavera/ inicio del verano (octubre-enero) que en el verano tardío (febrero-marzo). La talla del 50\% de madurez estimada para cada período fue 6.79 $\mathrm{mm}$ y $5.91 \mathrm{~mm}$ de LC respectivamente. Los resultados mostraron grandes diferencias con una población estuarial presumiblemente del sitio de origen (Japón), tales como menor longevidad, tallas máximas más pequeñas y menor talla de madurez.

Palabras clave: historia de vida, crecimiento, variabilidad intraespecífica, especie invasora, Caridea, reproducción.

\section{INTRODUCTION}

Knowledge of the life history traits of a species is essential to understand its ecology and population dynamics. Life-history theory predicts that organisms should allocate resources to the demands of maintenance, growth, reproduction, and storage in such a way as to maximize their fitness (Stearns 1992, 2000). As 
a consequence, when environmental conditions change in ways that alter the probability of survival or reproductive success, organisms may change their patterns of resource allocation in order to continue maximizing fitness (Schaffer 1974, Giesel 1976, Morris 1987, Winkler and Wallin 1987). Invasive species that are transported over long distances in short periods (e.g. marine species whose larvae travel in ballast water) have to face new environmental conditions during transport and in the introduced area that could be very different from those in their native environment. Life history traits that give invasive species the ability to develop successfully in new environments have been of continuous interest because of their potentially predictive power (Sakai et al. 2001).

The oriental shrimp, Palaemon macrodactylus, originally described by Rathbun (1902) from coastal populations in Japan, Korea and northern China, successfully colonized the northeastern Pacific coasts and estuaries after an accidental introduction in San Francisco Bay (Newman 1963), spreading north and southwards (Jensen 1995). Recently it was registered in the eastern coast of the United States and in the estuarine system of New York City (Warkentine and Rachlin 2010). In the southwestern Atlantic, the species was found on March 2000 in Mar del Plata harbour, Argentina, probably introduced from the Pacific with discharged ballast water (Spivak et al. 2006). The recent introduction in European waters also occurred through harbours (Ashelby et al. 2004, Cuesta et al. 2004, d'Udekem d'Acoz et al. 2005, González-Ortegón and Cuesta 2006, González-Ortegón et al. 2007, Béguer et al. 2007, Lavesque et al. 2010, Chicharo et al. 2009, Micu y Niţă 2009, St.Raykov et al. 2010, Soors et al. 2010). The distribution of the species in Asia, Europe and North America seems to be associated with estuarine or brackish water coastal areas, benefitting from the strong osmoregulatory capacity shown by adults (Born 1968, González-Ortegón et al. 2006)

The available information on $P$. macrodactylus deals with the geographic distribution (above references), ecological interactions (Cuesta et al. 2006, González-Ortegón et al. 2009), larval development (Little 1969), egg structure and infection (Fisher 1983a, Fisher 1983b, Fisher and Clark 1983), and morphological abnormalities (Béguer et al. 2008, 2010b). Although some life history traits have been documented in several estuaries (Siegfried 1980, González-Ortegón 2008, Béguer et al. 2011), the only comprehensive study of its life history was carried out in Japan by Omori and Chida (1988a), on a native population in brackish water.

The purpose of this paper was to study some life history traits (maturity size, relative growth, sex ratio, lifespan) and population dynamics of $P$. macrodactylus in a fully marine population of the shrimp in Mar del Plata harbour. Up to now, no other studies have been made on a population with these characteristics. Considering the salinity conditions prevailing in the

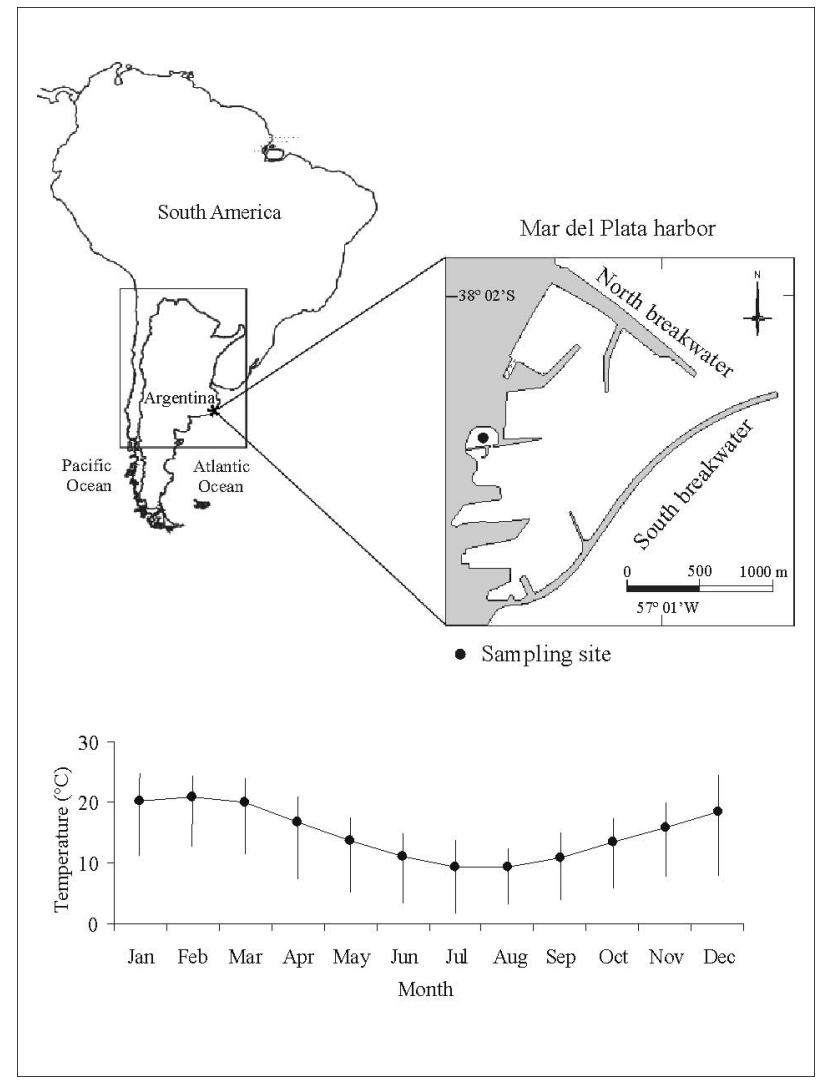

FIG. 1. - Palaemon macrodactylus. Study site in Mar del Plata harbour, Buenos Aires, Argentina (above), and surface sea water temperature (below). Average monthly temperatures (black dots) and monthly maximum and minimum (vertical bars) are indicated.

original area of the species and their current distribution after many invasive events, an adaptation of life history traits to low salinity conditions is expected. The working hypothesis is that several life history traits of this marine population will differ from those found in estuarine habitats.

\section{MATERIALS AND METHODS}

\section{Study area}

The study was carried out inside Mar del Plata harbour, Buenos Aires, Argentina (Fig. 1), which is one of the most important harbours in the country because of its fishing activity, naval traffic, commercial trade and recreational sailing. The environmental conditions correspond to those of a polluted site with high water turbidity, low dissolved oxygen and low $\mathrm{pH}$ (Rivero et al. 2005). Industrial and sewage effluents contribute to the increase in organic matter (Bastida et al. 1971). In spite of sewage discharges, seasonal heavy rainfall and poor water renewal (Bastida 1980), monthly average salinity ranges from 32.0 to 33.7 (Schwindt et al. 2010). Monthly average temperature ranges from $9.6^{\circ} \mathrm{C}$ in July to $21.9^{\circ} \mathrm{C}$ in February (Servicio de Hidrografía Naval) (Fig. 1). 
The harbour is limited by two artificial breakwaters (north and south), mainly composed of stone blocks, and its mouth is approximately $300 \mathrm{~m}$ wide. Mean water depth is around $5 \mathrm{~m}$, ranging between 3 and $10 \mathrm{~m}$. $P$. macrodactylus was collected from the piles of the piers.

\section{Sampling}

Samples of Palaemon macrodactylus were collected between March 2007 and March 2009, monthly during the first 18 months and every 10 to 15 days during the last 6 months, corresponding to the second reproductive period (November 2008 to March 2009).

Shrimps were caught with hand nets, frozen to kill the animals, fixed in $4 \%$ formalin for $24 \mathrm{~h}$ and finally transferred and stored in $70 \%$ alcohol.

\section{Sample analysis}

Each shrimp was measured under an SZ40 Olympus stereo microscope furnished with a micrometric eyepiece with an accuracy of $0.01 \mathrm{~mm}$. The recorded sizes were carapace length (CL), from the posterior orbital margin to the postero-dorsal border of the carapace and total length (TL), from the base of the eyestalks to the base of the telson. An additional measurement, the maximum width of the pleomere of the second abdominal segment (PW), was recorded from a group of ovigerous females with breeding dress, which is characterized by the presence of extra setae and enlargement of the abdominal brood pouch (Höglund 1943), collected during the reproductive period and from a group of non-reproductive females (without breeding dress) collected in winter.

The presence (males) or absence (females) of an appendix masculina in the second pleopod was the criterion for sex determination (Berglund 1981). Small individuals, below $3 \mathrm{~mm}$ CL, did not allow a clear visualization of that structure and were classified as undifferentiated juveniles.

Females were classified in terms of: a) reproductive condition (ovigerous and non-ovigerous) and b) ovary ripeness (Stage 1, ovary thin and translucent; Stage 2, ovary white or light green, occupying between one-quarter and one-half of the cephalothoracic dorsal surface; and Stage 3, ovary dark green or brown, occupying at least three quarters of the cephalothoracic dorsal surface). Immature females, resting mature females out of the reproductive season and recently spawned females had stage 1 ovary. Also, ovigerous females were assigned to one of three groups according to the embryonic development stage, based on the embryonic development characterization of Palaeomonetes argentinus (Ituarte et al. 2005): Stage I, ca. $100 \%$ of the volume occupied by yolk, embryos showing little or no differentiation; Stage II, ca. $50 \%$ to $60 \%$ yolk, eyes visible as a reddish line, heartbeat visible but often irregular; and Stage III, yolk largely depleted, eyes fully developed, heartbeat regular, differentiation of appendages in the final phase when individuals were ready to hatch.

\section{Statistical analysis}

A chi-square test was used to examine differences in the abundance of males and females over the sampling period and sex ratio departures from the expected 1:1 ratio.

Shrimps were grouped in size classes of $0.5 \mathrm{~mm}$ and size frequency distributions (SFD) were constructed separately for males and females. Undifferentiated juveniles were grouped with males to construct SFDs. Modal components of each SFD were estimated with the method developed by McDonald and Pitcher (1979) (see Bas et al. 2005 for details of procedure, parameters and restrictions of the method). Differences between consecutive modes were compared with one-way ANOVA and modal values were compared between males and females with one-way ANOVA for each mode separately.

The growth of $P$. macrodactylus was described by the seasonalized von Bertalanffy (VBGF) equation: $\mathrm{L}_{t}$ $=\mathrm{L}_{\infty}\left(1-\exp \left(-\mathrm{K}\left(\mathrm{t}-\mathrm{t}_{0}\right)-(\mathrm{CK} / л) \sin \left(2 л\left(\mathrm{t}-\mathrm{t}_{\mathrm{s}}\right)\right)\right)\right.$ (see Bilgin $e t$ al. 2009 for details of procedure, parameters and restrictions of the method). This is the usual von Bertalanffy model, where $\mathrm{Lt}$ is length at age $\mathrm{t}, \mathrm{L}_{\infty}$ is the asymptotic length to which the prawn grows, $\mathrm{K}$ is the growth-rate parameter, and $\mathrm{t}_{0}$ is the nominal age at which length is zero, with an extra term, (СК/л) $\sin \left(2 л\left(\mathrm{t}_{\mathrm{s}}\right)\right)$, which produces seasonal oscillations in the growth rate. The growth model was fitted separately for each sex. The growth curve was estimated by the Elefan I program (Pauly and David 1981).

The existence of changes in the relative growth of CL and PW during the non-reproductive phase of females was evaluated by comparing the CL vs TL and PW vs CL relationship in adult non-reproductive females (size above minimum ovigerous female CL but without breeding dress) and in young females (below the smallest size of ovigerous females) with the method described by Somerton (1980). The slopes and elevations of the Ln-transformed regression lines of data from non-reproductive females, reproductive females and males were compared using a Parallelism test (Zar 2010). The same procedure was applied to evaluate the relationship between PW and CL in reproductive and non-reproductive females.

The size of berried females was compared between months during the breeding season (October 2007 to March 2008) with a one-way ANOVA, and a Tukey test was performed subsequently to discriminate groups. Size at $50 \%$ of maturity was estimated separately for each previously determined group based on Somerton (1980) by fitting a logistic equation to the percentage of mature females (ovigerous females + non-ovigerous Stage 3 ovary females) in each one. 


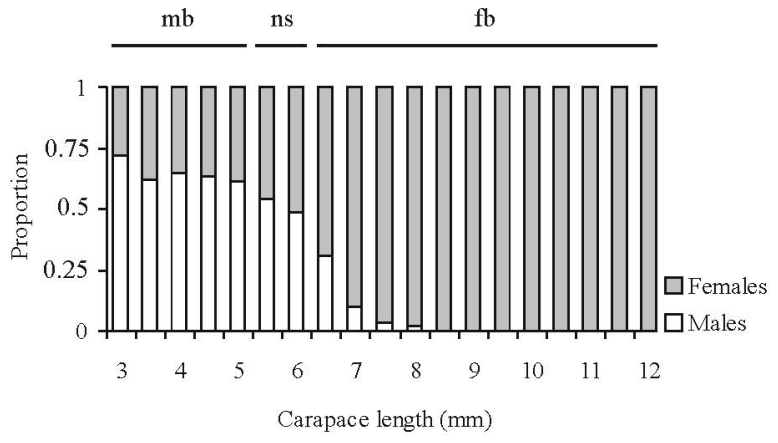

FIG. 2. - Palaemon macrodactylus. Sex ratios of the different size classes. mb: male biased $(P<0.0001)$; fb, female biased $(P<0.0001)$; $\mathrm{ns}$, non-differences between sexes proportion $(P>0.05)$. Class intervals, $0.5 \mathrm{~mm} \mathrm{CL}$.

\section{RESULTS}

\section{Population structure and dynamics}

The number of individuals collected for this study over two years was 4727: 2092 males, 2346 females (of which 526 were ovigerous) and 289 undifferentiated juveniles. The maximum CL was $7.50 \mathrm{~mm}$ for males and $12.50 \mathrm{~mm}$ for females.

The overall sex ratio $(47.13 \%$ males and $52.86 \%$ females) was biased to females $\left(\chi^{2}=4.71, P=0.029\right)$. Nevertheless, the sex ratio of each size class showed a significant bias towards males for class sizes 3 to $5 \mathrm{~mm}$ $\mathrm{CL}$ and towards females for class sizes starting at 6.50 $\mathrm{mm}$ CL. It was at equilibrium (1:1) for class size 5.50 and $6.00 \mathrm{~mm} \mathrm{CL}$ (Fig. 2).

The SFDs of shrimps were polymodal (Fig. 3). The smallest and largest size groups were not always present but the intermediate modes appeared in all samples, even though their proportion varied from month to month (Fig. 3). A total of seven modes were detected in male SFDs, nine in female SFDs and two in undifferentiated juveniles, represented in the male SFDs. These modes were named M1 to M9; M1 and M2 corresponded to undifferentiated juveniles, M3 to M7 to both males and females, and M8 and M9, the largest shrimps detected, were females. The comparison between modes of males and females showed no significant differences for M3 to M5 but females were larger in M6 and M7 (Fig. 4). Growth was evidenced by the shift of SFD modal classes to the right in successive months. However, the SFDs of June, July and August were almost identical (Fig. 3 ), suggesting that growth was interrupted during the cold season. Undifferentiated juveniles (=recruits) were recorded more or less continuously between the late spring and early autumn (December and March respectively; Fig. 3a).

Three cohorts were identified during the two-year sampling period, with only two of them coexisting during part of the year (Fig. 3). The cohort settled in summer, between December of one year and March of the next one, and disappeared totally around February

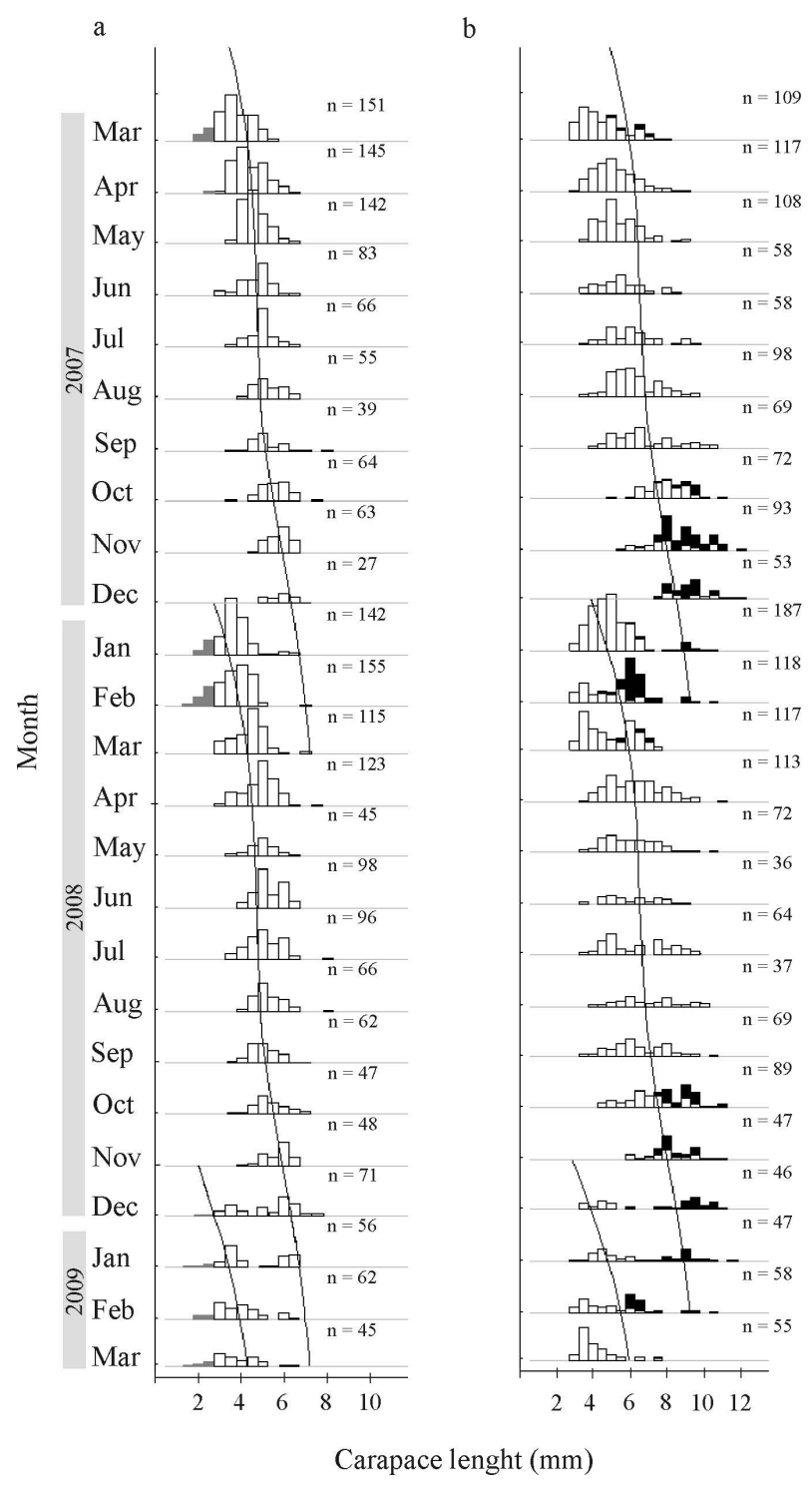

FIG. 3. - Palaemon macrodactylus. Size frequency distribution for a) males (white bars) and undifferentiated juveniles (grey bars); and b) non-ovigerous females (white bars) and ovigerous females (black bars). Vertical curve lines: average growth of each cohort (from Elefan I computer program).

TABle 1. - Palaemon macrodactylus. Average modal values of CL (carapace length) and growth increment (as a percentage) \pm standard deviation between consecutive modes. M1 to M9, Mode 1 to 9 of the SFD (size frequency distributions).

\begin{tabular}{lllll}
\hline \multirow{2}{*}{ Mode } & \multicolumn{2}{c}{ Males } & \multicolumn{2}{c}{ Females } \\
& CL $(\mathrm{mm})$ & Growth $(\%)$ & CL $(\mathrm{mm})$ & Growth $(\%)$ \\
\hline M1 & $2.07 \pm 0.28$ & $43.92 \pm 13.75$ & & \\
M2 & $2.82 \pm 0.28$ & $37.51 \pm 8.77$ & & \\
M3 & $3.88 \pm 0.27$ & $28.30 \pm 8.95$ & $3.92 \pm 0.26$ & $31.01 \pm 6.57$ \\
M4 & $5.05 \pm 0.27$ & $21.32 \pm 5.38$ & $5.17 \pm 0.26$ & $27.11 \pm 5.43$ \\
M5 & $6.13 \pm 0.37$ & $20.37 \pm 6.67$ & $6.57 \pm 0.23$ & $22.48 \pm 5.66$ \\
M6 & $7.16 \pm 0.52$ & $17.66 \pm 0.16$ & $8.03 \pm 0.34$ & $17.35 \pm 4.27$ \\
M7 & $8.13 \pm 0.18$ & & $9.44 \pm 0.24$ & $15.26 \pm 3.98$ \\
M8 & & & $10.88 \pm 0.35$ & $11.02 \pm 2.62$ \\
M9 & & & $12.03 \pm 0.21$ & \\
\hline
\end{tabular}




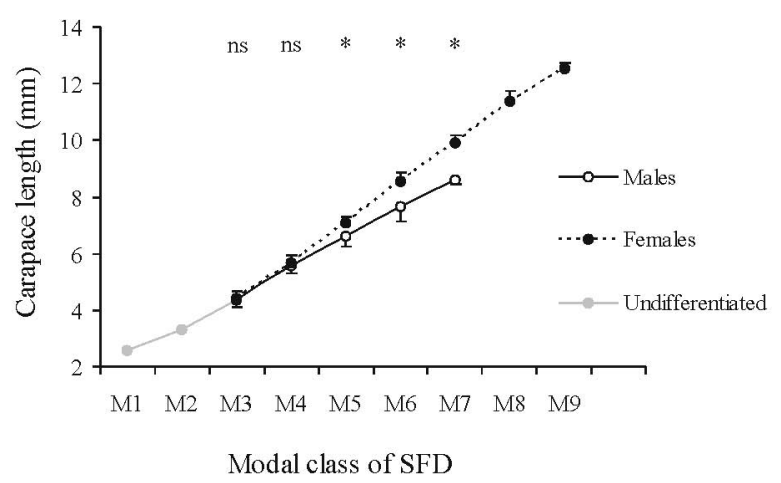

FIG. 4. - Palaemon macrodactylus. Average modal values $(\mathrm{CL} \pm \mathrm{sd})$ of males and females. ns, non-significant differences between sexes $(t$ test, $P>0.05)$; * : significant differences $(t$ test, $P<0.0001)$.

of the following year (Fig. 3), suggesting a longevity of 12 to 14 months.

The growth parameters obtained by Elefan fitted well to a seasonal model in which growth started in September (Fig. 3). The K coefficient was higher for females $\left(0.75\right.$ year $\left.^{-1}\right)$ than for males $\left(0.49\right.$ year $\left.^{-1}\right)$, as happened with the asymptotic size $\mathrm{L}_{\infty}(12.60 \mathrm{~mm} \mathrm{CL}$ for females and $11.00 \mathrm{~mm}$ CL for males).

\section{Morphological relationship}

There were no differences in the slope of lines of CL vs TL and PW vs CL belonging to non- reproductive females above and below the size at maturity (estimated for the total of females using the size of the smallest ovigerous female as the lower limit for mature females; see below in size at maturity section) and, consequently, data from all non-reproductive females were pooled and compared with male and reproductive female growth lines. The results of the analysis of the regression of Ln-transformed data obtained for CL vs TL for males and reproductive and non-reproductive females and from PW vs CL for reproductive and non-reproductive females are summarized in Figure 5 (all regression coefficients were significantly different from zero, $P=0.001)$.

In all cases, CL increased linearly and positively with TL. Slopes differed between non-reproductive and reproductive females and between males and nonreproductive females (Parallelism test, $P<0.0001$ ) (Fig. 5a). The maximum slope corresponded to non-reproductive females. The change in CL between reproductive and non-reproductive females associated with the acquisition of the breeding dress was maximum at the minimum size of reproductive females (about 20.00 $\mathrm{mm}$ TL), decaying afterward until no differences existed in CL in the largest females (Fig. 5a). Regression lines of PW vs CL differed between reproductive and non-reproductive females in a way similar to the above mentioned relationship (Parallelism test, $P<0.0001$ ) (Fig. 5b).
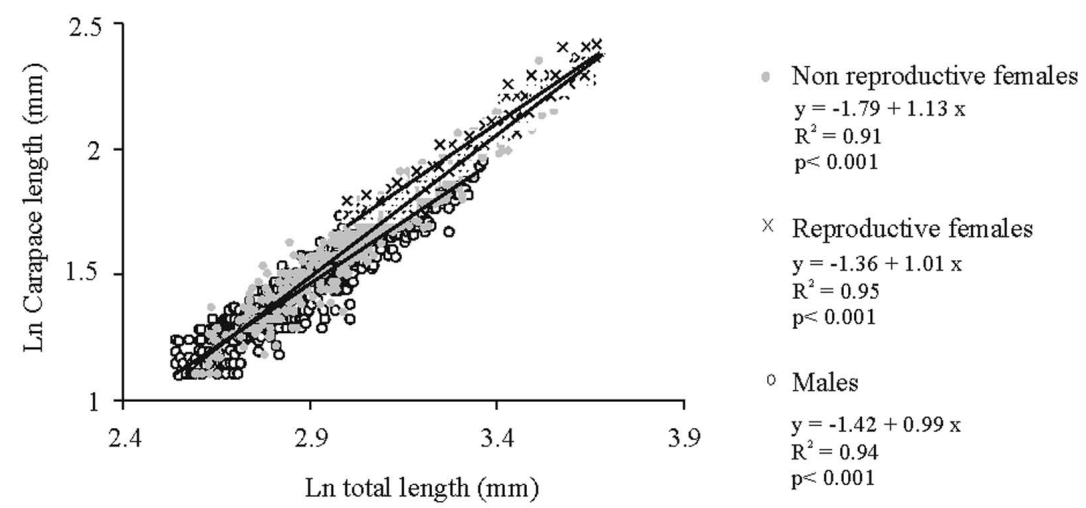

b

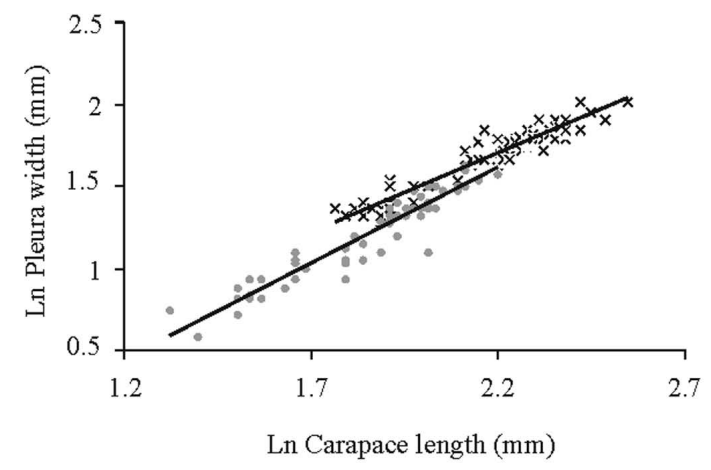
Non reproductive females $y=-0.42+0.96 x$ $\mathrm{R}^{2}=0.91$ $\mathrm{p}<0.001$
$\times$ Reproductive females $y=-0.96+0.17 x$ $\mathrm{R}^{2}=0.90$ $\mathrm{p}<0.001$

Ln Carapace length ( $\mathrm{mm}$ )

FIG. 5. - Palaemon macrodactylus. Relationship between a) carapace length (CL) and total body length (TL) in reproductive females, nonreproductive females and males; and b) pleon width of the second abdominal somite (PW) and carapace length (CL) in reproductive and non-reproductive females. 


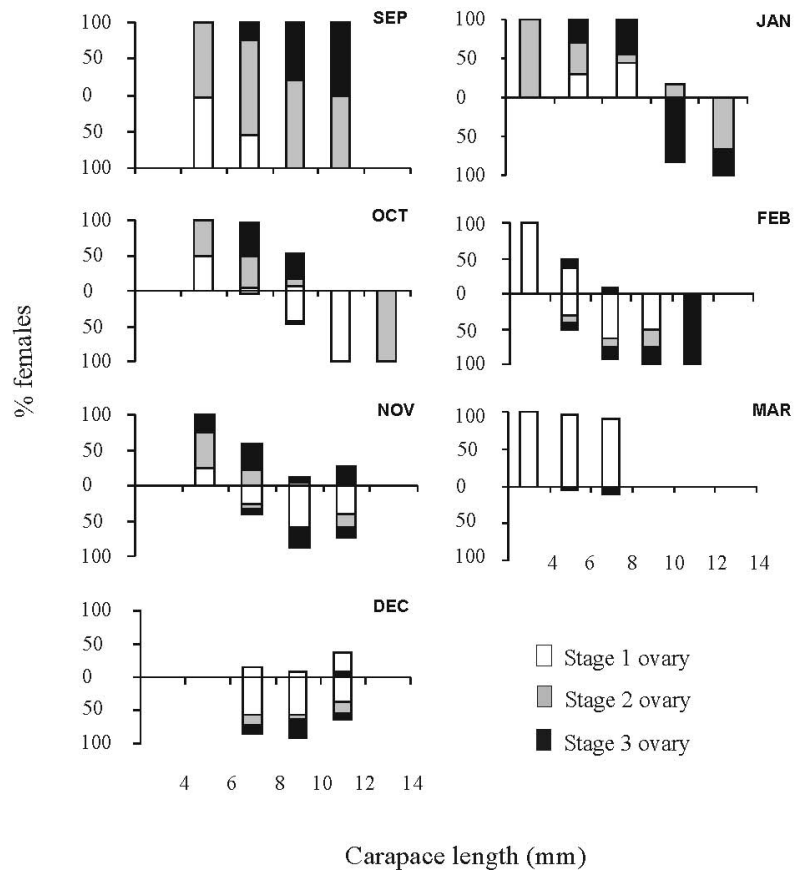

FIG. 6. - Palaemon macrodactylus. Ovarian stages of non-ovigerous (above $\mathrm{X}$-axis) and ovigerous (below $\mathrm{x}$-axis) females sampled throughout one reproductive season, between September 2007 and March 2008.

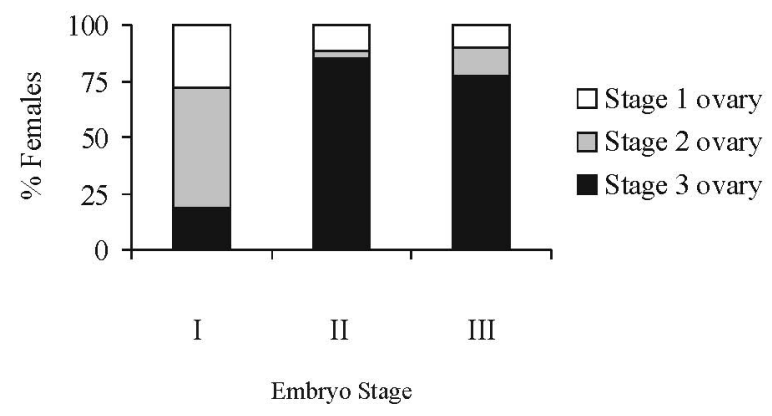

FIG. 7. - Palaemon macrodactylus. Relationship between ovarian ripeness of ovigerous females (Stages 1,2 and 3) and embryo maturity (Stages I, II and III).

\section{Reproduction}

Two complete reproductive periods were recorded, between October 2007 and March 2008 and between October 2008 and March 2009. The highest percentages of ovigerous females appeared in December 2007 (84.9\%) and November 2008 (68.0\%). An abrupt decrease was observed in January in 2007 but not in the following year (Fig. 3b).

\section{Size at maturity}

The smallest ovigerous female measured $4.65 \mathrm{~mm}$ $\mathrm{CL}$ and the smallest mature (Stage 3 ovary) but nonovigerous female measured $4.50 \mathrm{~mm} \mathrm{CL}$, both in February 2008. The largest ovigerous female appeared in October 2007 and measured $12.50 \mathrm{~mm}$ CL. The size at maturity differed between months (considering the complete sampling period of two years) (ANOVA test, $P<0.001)$. Based on the between-pairs a posteriori comparisons, two different groups were evidenced, one formed by females from October, November, December and January and the other by females from February and March. The estimated sizes for 50\% of sexual maturity $\left(\mathrm{SM}_{50}\right)$ were $6.79 \mathrm{~mm} \mathrm{CL}$ for the first group and $5.91 \mathrm{~mm} \mathrm{CL}$ for the second one.

\section{Ovarian cycle}

Gonad maturation of females occurred from September to March (outside this period only Stage 1 ovaries were observed). Figure 6 shows the maturity stage of ovaries at each size class of non-ovigerous and ovigerous females throughout the reproductive season. In September only large females had mature ovaries and they become ovigerous in the following month, while smaller females reached maturity and continued growing. From November, the largest females were not present; in December all females were larger than 6.00 $\mathrm{mm} \mathrm{CL}$ and most of them were ovigerous. In January a new group of small females was incorporated into the reproductive population. In February, in contrast with what was observed at the beginning of the season, part of the females below $6.00 \mathrm{~mm}$ CL became ovigerous, resulting in the smallest ovigerous size in the whole summer season. By March ovigerous females had almost disappeared from samples and all the non-ovigerous had ovaries in Stage 1.

While nearly $75 \%$ of the ovigerous females with embryos in Stage I had their ovaries in Stage 1 or 2, those with embryos in Stages II or III had mainly mature ovaries (Stage 3) (Fig. 7).

\section{DISCUSSION}

The life history of an organism is the series of adaptations or strategies tending to maximize its reproductive success and variations in life-history strategies have been found in caridean shrimps (Bauer 2004). Among life-history traits, sex ratio is closely related to reproductive strategies of species, with natural selection commonly favouring the proportion 1:1 (Fisher 1958). A sex ratio different from 1:1 could be attributed to one of five interpretations: longevity factor, differential migration, differential mortality, differential growth rates and sex reversal (Wenner 1972). The total sex ratio of the Mar del Plata harbour population of Palaemon macrodactylus was biased to females. Predation by females on males, which could explain the deviation, was reported by Omori and Chida (1988b) in this species and observed by us in laboratory cultures (differential mortality). On the other hand, the male-biased ratio in individuals smaller than $5.25 \mathrm{~mm}$ CL may be an effect of accumulation. Considering the whole size range of the species, the total number of males, which grow less than females, tend to be "cu- 
TABLE 2. - Palaemon macrodactylus. Life history traits from different populations in the original and invaded areas. CL, carapace length $(\mathrm{mm})$; TL, total length (mm); F, females; M, males; nd, no data available

\begin{tabular}{|c|c|c|c|c|c|c|c|c|c|}
\hline & \multicolumn{2}{|c|}{ Maximum CL } & \multicolumn{2}{|c|}{ Maximum TL } & \multicolumn{2}{|c|}{$\begin{array}{l}\text { Smallest } \\
\text { ovigerous }\end{array}$} & \multirow[t]{2}{*}{$\begin{array}{l}\text { Reproductive } \\
\text { period }\end{array}$} & \multirow{2}{*}{\multicolumn{2}{|c|}{$\begin{array}{l}\text { Life span Reference } \\
\text { (years) }\end{array}$}} \\
\hline & $\mathrm{F}$ & M & $\mathrm{F}$ & M & $\mathrm{CL}^{\circ}$ & $\mathrm{TL}$ & & & \\
\hline Mar del Plata harbour (Argentina) & 12.5 & 7.5 & 45.3 & 31.5 & 4.5 & 16.8 & October-March & 1 & This paper \\
\hline Matsushima Bay (Japa & 16.7 & 11.7 & nd & nd & 8.5 & nd & April-October & 2 & Omori and Chid \\
\hline San Francisco Bay (EEUU) & nd & nd & 55.0 & 40.0 & nd & 23.0 & April-August & nd & Siegfried 1980 \\
\hline r Estuary (Spain) & 14.1 & 8.9 & nd & nd & 6.2 & nd & April-September & nd & González-Ortegón 2008 \\
\hline Gironde Estuary (France) & 13.1 & 9.5 & nd & nd & nd & nd & April-September & nd & Béguer et al. 2011 \\
\hline Orwell estuary (Suffolk, UK) & nd & nd & 70.0 & 35.0 & nd & 65.0 & June-September & nd & Ashelby et al. 2004 \\
\hline Black Sea (Romania) & 15.8 & nd & nd & nd & 5.9 & nd & April-October & nd & Micu and Niță 2009 \\
\hline North Sea (Netherland) & nd & nd & 61.0 & nd & nd & nd & nd & nd & d'Udekem d'Ácoz et al. 2005 \\
\hline
\end{tabular}

mulated" in the size classes below $7.25 \mathrm{~mm}$ CL, while females are distributed in a broader range (differential growth rate).

Sexual dimorphism is a common trait in carideans and is related to different types of mating systems. Many species have relatively large females and small males, generally associated with a "pure searching" mating strategy (Bauer 2004). Sexual dimorphism in size is very pronounced in $P$. macrodactylus, with females reaching larger sizes than males, as has been observed in other Palaemon species: P. xiphias (Guerao 1994), P. longirostris (Cartaxana 2003), P. adspersus (Manent and Abella-Gutiérrez 2006), P. paucidens (Kim et al. 2008). Berglund (1981) summarized the factors promoting the increase or decrease in body size in Palaemon shrimps: the larger size in females may be related to an increased capacity for carrying eggs, and the smaller size of the males may provide them with greater mobility, simultaneously favouring the number of mates and reducing the risks of predation. Regardless the factor involved, females of $P$. macrodactylus had higher $\mathrm{K}$ values than males, as occurred in other Palaemon species: P. paucidens (Kim et al. 2008, P. serrifer (Shungan 2008) and $P$. adspersus (Bilgin et al. 2009). In addition, differences between sexes were observed in the relative growth of carapace. The faster carapace growth in relation to total length detected in females could be explained by their much more developed gonads. This pattern of relative growth is also exhibited by other palaemonids such as $P$. northropi, $P$. pandaliformis, Macrobrachium acanthurus and $M$. olfersii (Anger and Moreira 1998), and Creaceria morleyi (Botello and Alvarez 2006).

The growth rate of PW in non-reproductive females of $P$. macrodactylus was constant along the whole size range, and the gain in volume of the incubation chamber produced by the moulting to a reproductive condition (breeding dress) was greater in small females. The pattern of relative growth varies among different species of the genus. For example it differed between $P$. macrodactylus and $P$. longirostris: a break existed in the PW vs CL relationship in non-reproductive females of the latter, with a decay in the growth rate of mature females and the increase in PW during moulting to the reproductive form was constant along the whole size range of mature females (Béguer et al. 2010a).
It is commonly accepted that the investment of energy in reproduction reduces growth, particularly in females, which frequently have a higher reproductive investment than males and, as a consequence, have to decouple growth and reproduction in many species (Hartnoll 1985). In addition, during the breeding period, females that carry eggs cannot moult and therefore growth is inhibited (Oh et al. 2003). Nevertheless, the growth of both males and females of $P$. macrodactylus was seasonal, started in September and finished in April, in accordance with the reproductive season. This species, like other species of Palaemon (Berglund 1981, Emmerson 1986), halted growth during the period of low temperature and grew and reproduced during the warmer period (this study; Omori and Chida 1988a). On the other hand, females of $P$. macrodactylus are successive breeders, producing brood continuously one after another, until death or the end of the reproductive season, like many other small-bodied species in tropical and temperate zones (Bauer 1989, Bauer and Van Hoy 1996). It was observed in this study that most females carrying embryos ready to hatch had ovaries ready to spawn a new brood. Accordingly, Omori and Chida (1988b) reported a frequency of spawning of up to nine times in $P$. macrodactylus in the laboratory. The ability to invest energy simultaneously in growth and reproduction and the possibility of producing many successive broods would be important to explain the successful invasion of new habitats (together with a broad physiological tolerance, see below).

Different populations of caridean species occupying different habitats can be locally adapted to or affected by different sets of environmental conditions (Ituarte et al. 2007, Campos et al. 2009). Though many studies have reported the presence of $P$. macrodactylus in different habitats around the world, the available information regarding life history and population traits is scarce and fragmentary (Table 2). The presence of this species in areas with salinities that may reach values typical of marine waters has been mentioned, but no details of their life history and population dynamics have been provided (Ashelby et al. 2004, Lavesque et al. 2010). Consequently, this is the first comparison of population dynamics and life history traits of $P$. macrodactylus between a population in a fully marine area (Mar del Plata harbour) and estuarine populations. 
The population of $P$. macrodactylus in the Mar del Plata harbour showed a clear seasonal pattern of reproduction, settlement and growth. Some important differences are evident when this life cycle is compared with that in Matsushima Bay, in the native geographical range of the species (Omori and Chida 1988a). In Matsushima, three age groups $(0+, \mathrm{I}+$ and $\mathrm{II}+)$ were recognized, representing three different coexisting cohorts, and the life span was about two years; the maximum sizes of males and females were larger $(36 \%$ and $39 \%$ respectively) than in Mar del Plata, where the longevity was estimated as one year (Omori and Chida 1988 a, this paper). The life span alone does not explain the difference in maximum size, since at the end of the first year, the individuals in Matsushima reached a larger size than those in Mar del Plata; consequently, the initial size of settlers and/or the increment per moult and/or the moult frequency should be different between populations. In addition, the minimum size at maturity differed between populations, being $8.00 \mathrm{~mm}$ CL in Matsushima (biological minimum sensu Omori and Chida 1988a) and 4.65 mm CL in Mar del Plata.

On the other hand, the two populations showed a similar pattern of decrease in the size of reproductive females during the breeding period: at the beginning (spring), reproductive females were represented only by the largest ones. Later, they had an intermediate average size, since not only the largest but all the adult females were reproductive. Finally, during the last part of the season, large females died and a new group of small females were incorporated into the reproductive population, reducing the average size of the group. However, whereas in Matsushima the three female groups corresponded to different cohorts (II+, I+ and 0 sensu Omori and Chida 1988a), in Mar del Plata the intermediate and largest groups were both from the same year, the difference being due to the moment of settlement. The first females settled in the season grew, became the smallest ovigerous females at the end of the same season, and finally were the largest ones found at the beginning of the following season. The last females settled in the season reached maturity only at the beginning of the following season (since growth is arrested in winter), reproduced for the first time in the middle of that season and reached the intermediate size of ovigerous females. It is worth noting that females from the $6 \mathrm{~mm}$ size class were reproductive at the end but not at the beginning of the season, suggesting that the two groups differ not only in the time of settlement but also in other physiological traits.

The main factor responsible for growth variations in ectothermic animals is temperature (Ponce-Palafox et al. 1997). The range of temperatures during the breeding season differed between Matsushima (14$27^{\circ} \mathrm{C}$; Omori and Chida 1988a) and Mar del Plata (9.6-21.9 ${ }^{\circ} \mathrm{C}$, average values from the Servicio de Hidrografía Naval, Argentina). The markedly higher maximum temperature in Japan could cause the observed higher growth rate, although the extent of the annual periods of reproduction, growth and settlement are the same in both populations.

Salinity, another factor that has potential effects on growth, (Alon and Stancyk 1982), differed between sites. The Mar del Plata population of P. macrodactylus is restricted to the harbour, a fully marine environment, whereas shrimps in Matsushima Bay were collected from an estuarine zone, although no details were provided about the precise salinity in the area. Inter-population differences have been reported in Caridea regarding the size of embryos and larvae among populations living in different salinities, which could affect the adult size; however, the effect of high or low salinities varied, and is probably related to the evolutionary history of species (Alon and Stancyk, 1982, Mashiko 1990, Ituarte et al. 2007). In a recently established population of $P$. macrodactylus in the estuary of the Guadalquivir River (Spain), González-Ortegón (2008) recorded intermediate maximum sizes and size at maturity between those of Japan and Argentina. Comparative studies on growth under different salinity regimes are not available for this species.

Predation is another factor commonly recognized as modelling the maximum size and size at maturity of many species (Alon and Stancyk 1982, Reznick and Endler 1982, Beckerman et al. 2007) and it could be responsible for the observed differences. However, no information is available about predation pressure on $P$. macrodactylus at any of the localities.

In summary, $P$. macrodactylus, a typical resident of estuarine/brackish temperate waters, is able to develop successfully in fully marine conditions and to reproduce in different temperature ranges. Attrill and Rundle (2002) proposed that the status of "estuarine species" has no real entity, and that this transitional environment is in fact occupied by marine and freshwater species with a physiological background that allows them to cope with changing intermediate salinities. Nevertheless, the smaller maximum size, size at maturity and shorter life span that were observed suggest a more stressing situation for this species in marine conditions. Whether this stress is caused by a physical factor such as salinity or a biological one such as predation will require further research.

\section{ACKNOWLEDGEMENTS}

This paper was funded by grants EXA 527/10 from the Universidad Nacional de Mar del Plata and PIP 176/09-11 from the Consejo Nacional de Investigaciones Científicas y Técnicas de Argentina (CONICET) (PICT 21757). MGV has a graduate fellowship from CONICET and the results of this study will be part of her doctoral dissertation.

\section{REFERENCES}

Alon N.C., Stancyk S.E. 1982. Variation in life-history patterns of the grass shrimp Palaemonetes pugio in two south Carolina estuaries systems. Mar. Biol. 68: 265-276. 
Anger K., Moreira G.S. 1998. Morphometric and reproductive traits of tropical caridean shrimps. J.Crustac. Biol. 18: 823-838.

Ashelby C.W., Worsfold T.M., Fransen C.H.J.M. 2004. First records of the oriental prawn Palaemon macrodactylus (Decapoda: Caridea), an alien species in European waters, with a revised key to British Palaemonidae. J. Mar. Biol. Ass. U. K. 84: 1041-1050.

Attrill M.J., Rundle S.D. 2002. Ecotone or Ecocline: Ecological Boundaries in Estuaries. Estuar. Coast. Shelf Sci. 55: 929-936.

Bas C., Luppi T., Spivak E. 2005. Population structure of the South American estuarine crab, Chasmagnathus Granulatus (Brachyura: Varunidae) near the southern limit of its geographical distribution: comparison with northern populations. Hydrobiologia 537: 217-228.

Bastida R.O., Capezzani D.A.A., Torti M.R. 1971. Fouling organisms in the port of Mar del Plata (Argentina). I. Siphonaria les soni: ecological and biometric aspects. Mar. Biol. 10: 297-307

Bastida R.O., Trivi M., Lichtschein V., Stupak M. 1980. Ecological aspects of marine fouling at the port of Mar del Plata (Argentina). V Congreso Internacional de Corrosión marina e Incrustaciones. Barcelona, España, pp. 299-320.

Bauer R.T. 1989. Continuous reproduction and episodic recruitment in nine shrimp species inhabiting a tropical seagrass meadow. $J$. Exp. Mar. Biol. Ecol. 127: 175-85.

Bauer R.T. 2004. Remarkable Shrimps: Adaptations and Natural History of the Carideans. University of Oklahoma Press, Norman, $282 \mathrm{pp}$.

Bauer R.T., VanHoy R. 1996. Variation in sexual systems (protandry, gonochorism) and reproductive biology among three species of the shrimp genus Thor (Decapoda: Caridea) Bull. Mar. Sci. 59: 53-73

Beckerman A.P., Wieski K., Baird D.J. 2007. Behavioural versus physiological mediation of life history under predation risk. Oecologia. 152: 335-343.

Béguer M., Bergé J., Giardin M., Boët, P. 2010a. Reproductive biology of Palaemon longirostris (Decapoda: Palaemonidae) from Gironde estuary (France), with a comparison with other European populations. J. Crustac. Biol. 30: 175-185.

Béguer M., Bergé J., Martin J., Martinet J., Pauliac G., Girardin M., Boët P. 2011. Presence of Palaemon macrodactylus in a European estuary: evidence for successful invasion of the Gironde (SW France). Aquat. Inv. 6: 301-318.

Béguer M., Feuillassier L., Elie P., Boët P., Girardin M. 2010b. Exoskeletal deformities in Palaemonidae: Are they a threat to survival? Mar. Environ. Res. 69: 109-117.

Béguer M., Girardin, M., Boët, P. 2007. First record of the invasive oriental shrimp Palaemon macrodactylus. Rathbun, 1902 in France (Gironde estuary). Aquat. Inv. 2: 132-136.

Béguer M., Pasquaud S., Boët C., Noël P., Girardin M. 2008. First description of main skeletal deformations in shrimps populations of the Gironde estuary (France). Hydrobiologia 607 225-229.

Berglund A. 1981. Sex dimorphism and skewed sex ratios in the prawn species Palaemon adspersus and P. squilla. Oikos 36: $158-162$.

Bilgin S., Samsun O., Ozen O. 2009. Seasonal growth and reproduction biology of the Baltic prawn, Palaemon adspersus (Decapoda: Palaemonidae), in the southern Black Sea. J. Mar. Biol. Ass. U. K. 89: 509-519.

Born J.W. 1968. Osmoregulatory capacities of two caridean shrimps: Syncaris pacifica (Atyidae) and Palaemon macrodac tylus (Palaemonidae). Biol. Bull. 134: 235-244.

Botello A., Alvarez F. 2006. Allometric growth in Creaseria morleyi (Creaser, 1936) (Decapoda: Palaemonidae), from the Yucatan Peninsula, Mexico. Caribb. J. Sci. 42: 171-179.

Campos J., Pedrosa C., Rodrigues J., Santos S., Witte J.I.J., Santos P., Van der veer H.W. 2009. Population zoogeography of brown shrimp Crangon crangon along its distributional range based on morphometric characters. J. Mar. Biol. Ass. U. K. 89: 499-507.

Cartaxana A. 2003. Growth of the prawn Palaemon longirostris (Decapoda, Palaemonidae) in Mira river and estuary, SW Portugal. J. Crustac. Biol. 23: 251-257.

Chicharo M.A., Leitão T., Range P, Gutierrez C., Morales J., Morais P., Chicharo L. 2009. Alien species in the Guadiana Estuary (SE-Portugal/SW-Spain): Blackfordia virginica (Cnidaria, Hydrozoa) and Palaemon macrodactylus (Crustacea, Decapoda): potential impacts and mitigation measures. Aquat. Inv.
4. 501-506.

Cuesta J.A., González-Ortegón E., Drake P., Rodríguez A. 2004. First record of Palaemon macrodactylus Rathbun, 1902 (Decapoda, Caridea, Palaemonidae) from European waters. Crustaceana 77 : $377-380$.

Cuesta J.A., González-Ortegón E., Rodríguez A., Baldo F., Vilas C., Drake P. 2006. The decapod crustacean community of the Guadalquivir Estuary (SW Spain): seasonal and inter-year changes in community structure. Hydrobiologia 557: 85-95.

d'Udekem d'Acoz C.U., Faasse M., Dumoulin E., De Blauwe H. 2005. Occurrence of the Asian shrimp Palaemon macrodactylus in the Southern Bight of the North Sea, with a key to the Palaemonidae of north-western Europe (Crustacea: Decapoda: Caridea). Ned. Faunist. Meded. F.M. 22: 95-111.

Emmerson W.D. 1986. The ecology of Palaemon pacificus (Stimpson) associated with Zostera capensis. Setchell. Trans. Royal Soc. South Africa 46: 79-97.

Fisher R.A. 1958. The Genetical Theory of Natural Selection. Dover, New York, $219 \mathrm{pp}$

Fisher W.S. 1983a. Eggs of Palaemon macrodactylus. II. Association with aquatic bacteria. Biol. Bul. 164: 201-213.

Fisher W.S. 1983b. Eggs of Palaemon macrodactylus. III. Infection by the fungus Lagenidium callinectes. Biol. Bull. 164: 214-226.

Fisher W.S., Clark W.H. 1983. Eggs of Palaemon macrodactylus. I. Attachment to the pleopods and formation of the outer investment coat. Biol. Bull. 164: 189-200

Giesel J.T. 1976. Reproductive strategies as adaptations to life in temporally heterogeneous environments. Ann. Rev. Ecol. Syst. 7: 57-79.

González-Ortegón E. 2008. Ecología de los crustáceos decápodos en el necton del estuario del Guadalquivir. Efectos de la introducción de Palaemon macrodactylus. PhD thesis. Univ. Cádiz. 314 pp.

González-Ortegón E., Cuesta J.A. 2006. An illustrated key to species of Palaemon and Palaemonetes (Crustacea: Decapoda: Caridea) from European waters, including the alien species Palaemon macrodactylus. J. Mar. Biol. Ass. U. K. 86: 93-102.

González-Ortegón E., Cuesta J.A., Pascual, E., Drake P. 2009. Assessment of the interaction between the white shrimp, Palaemon longirostris, and the exotic oriental shrimp, Palaemon macrodactylus, in a European estuary (SW Spain). Biol. Invas. 12: $1731-1745$

González-Ortegón E., Pascual E., Cuesta J.A., Drake P. 2006. Field distribution and osmoregulatory capacity of shrimps in a temperate European estuary (SW Spain). Est. Coast. Shelf Sci. 67: 293-302.

González-Ortegón E., Cuesta J.A., Schubart C.D. 2007. First report of the oriental shrimp Palaemon macrodactylus Rathbun, 1902 (Decapoda, Caridea, Palaemonidae) from German waters. Helgoland Mar. Res. 61: 67-69.

Guerao G., Pérez-Baquera J., Ribera C. 1994. Growth and reproductive biology of Palaemon xiphias Risso, 1816 (Decapoda, Caridea, Palaemonidae). J. Crustac. Biol. 14: 280-288.

Hartnoll R.G. 1985. Growth, sexual maturity and reproductive output. In: Wenner A.M. (ed.), Factors in adult growth, Crustacean Issues, 3. A.A. Balkema, Rotterdam, pp. 101-128.

Höglund H. 1943. On the biology and larval development of Leander squilla (L.) forma typica De Man. Sven. Hydrogr. Biol. Komm. Skr. Ny Ser Biol. Band II, No. 6

Ituarte R.B., Spivak E.D., Anger K. 2005. Effects of salinity on embryonic development of Palaemonetes argentinus (Crustacea: Decapoda: Palaemonidae) cultured in vitro. Invertebr. Reprod. Dev. 47: 213-223.

Ituarte R.B., Spivak E.D., Anger K. 2007. Intraspecific variability in life-history traits of a "freshwater shrimp", Palaemonetes argentinus. Ann. Limnol. 43: 293-302.

Jensen G.C. 1995. Pacific Coast: Crabs and Shrimps. Sea Challengers, Monterey, California, $85 \mathrm{pp}$.

Kim J.C., Ma C.W., Oh C.W., Paik S.G. 2008. Reproduction and growth of the freshwater prawn, Palaemon paucidens (Decapoda: Palaemonidae) in a lake of Korea. J. Environ. Biol. 29: 163-168.

Lavesque N., Bachelet G., Béguer M., Girardin M., Lepage M., Blanchet H., Sorbe J-C., Modéran J., Sauriau P-G., Auby I. 2010. Recent expansion of the oriental shrimp Palaemon macrodactylus (Crustacea: Decapoda) on the western coasts of France. Aquat. Invas. 5: S103-S108, doi:10.3391/ai.2010.5.S1.021. 
Little G. 1969. The larval development of the shrimp, Palaemon macrodactylus Rathbun, reared in the laboratory, and the effect of eyestalk extirpation on development. Crustaceana 17: 69-87.

Manent P., Abella-Gutiérrez J. 2006. Population biology of Palaemon adspersus Rathke, 1837 (Decapoda, Caridae) in Fornells Bay, Balearic Islands, western Mediterranean. Crustaceana 79: 1297-1308.

Mashiko K. 1990. Diversified egg and clutch sizes among local populations of the fresh-water prawn Macrobrachium nipponense (de Haan). J. Crustac. Biol. 10: 306-314.

McDonald P.D., Pitcher T. J. 1979. Age groups from size-frequency data: a versatile and efficient method of analyzing distribution mixtures. J. Fish. Res. Board. Can. 36: 987-1001.

Micu D., Niţă V. 2009. First record of the Asian prawn Palaemon macrodactylus Rathbun, 1902 (Caridea: Palaemonoidea: Palaemonidae) from the Black Sea. Aquat. Invas. 4: 597-604.

Morris D.W. 1987. Spatial scale and the cost of density-dependent habitat selection. Evol. Ecol 1: 379-388.

Newman W.A. 1963. On the introduction of an edible oriental shrimp (Caridea, Palaemonidae) to San Francisco Bay. Crustaceana 5: 119-132.

Oh, C.W., Ma C.W., Hartnoll R.G., Suh H.L. 2003. Reproduction and population dynamics of the temperate freshwater shrimp, Neocaridina denticulate deticulata (De Haan, 1844), in a Korean stream. Crustaceana 76: 993-1015

Omori M., Chida Y. 1988a. Life history of a caridean shrimp Palaemon macrodactylus with special reference to the difference in reproductive features among ages. Nippon Suisan Gakkaishi 54: 365-375.

Omori M., Chida Y. 1988b. Reproductive ecology of a caridean shrimp Palaemon macrodactylus in captivity. Nippon Suisan Gakaishi 54: 377-383

Pauly D., David N. 1981. ELEFAN I, a basic program for the objective extraction of growth parameters from length-frequency data. Meeresforschung 28: 205-211.

Ponce-Palafox J., Martinez-Palacios C.A., Ross L.G. 1997. The effects of salinity and temperature on the growth and survival rates of juvenile white shrimp, Penaeus vannamei, Boone 1931. Aquaculture 157: 107-115.

Rathbun M. 1902. Japanese stalk-eyed crustaceans. Proceedings of the United States National Museum 26: 23-55

Reznick D., Endler J.A. 1982. The impact of predation on life history evolution in Trinidadian Guppies (Poecilia reticulata). Evolution 36: 160-177.

Rivero M.S., Vallarino E., Elías R. 2005. First survey of macroinfauna in the Mar del Plata Harbor (Argentina), and the use of polychaetes as pollution indicators. Rev. Biol. Mar. Oceanogr. 40: 101-108.

Sakai A.K., Allendorf F.W., Holt J.S., Lodge D.M., Molofsky J.,
With K.A., Baughman S., Cabin R.J, Cohen JE., Ellstrand N.C., McCauley D.E., O’Neil P., Parker I.M., Thompson J.N., Weller S.G. 2001. The population biology of invasive species. Annu. Rev. Ecol. Syst. 32: 305-332.

Schaffer W.M. 1974. Selection for optimal life histories: the effects of age structure. Ecology. 55: 291-303.

Schwindt E., Darrigan G., Repizo H. 2010. Evaluación Nacional de Situación en Materia del Agua de Lastre en el Litoral Marino y Fluvial, Argentina. Informe Final. Proyecto Globallast. $334 \mathrm{pp}$.

Siegfried C.A. 1980. Seasonal abundance and distribution of Crangon franciscorum and Palaemon macrodactylus (Decapoda, Caridea) in the San Francisco Bay-Delta. Biol. Bull. 159: 177-192.

Somerton D.A. 1980. A computer technique for estimating the size of sexual maturity in crabs. Can. J. Fish. Aquat. Sci. 37: $1488-1494$

Soors J., Faasse M., Stevens M., Verbessem I., De Regge N., Van den Bergh E. 2010. New crustacean invaders in the Schelde estuary (Belgium). Belg. J. Zool. 140(1): 3-10.

Spivak E.D., Boschi E.E., Martorelli S.R. 2006. Presence of Palaemon macrodactylus (Rathbun 1902) (Crustacea: Decapoda: Caridea: Palaemonidae) in Mar del Plata harbor, Argentina: first record from southwestern Atlantic waters. Biol. Invas. 8: 673-676.

St. Raykov V., Lepage M., Pérez-Domínguez R. 2010. First record of oriental shrimp, Palaemon macrodactylus Rathbun, 1902 in Varna Lake, Bulgaria. Aquat. Invas. 5: S91-S95

Stearns S.C. 1992. The evolution of life histories. Oxford University Press. Oxford. New York. pp. 1-249.

Stearns S.C. 2000. Life history evolution: successes, limitations, and prospects. Naturwissenschaften 87:476-486.

Sunghan K. 2008. Growth, fecundity, egg size and recruitment of Palaemon serrifer. (Decapoda: Caridea: Palaemonidae) J. Ecol. Field Biol. 31: 9-15

Warkentine B.E., Rachlin J.W. 2010. The first record of Palaemon macrodactylus (Oriental Shrimp) from the eastern coast of North America northeastern. Naturalist 17: 91-102.

Wenner A.M. 1972. Sex-ratio as a function of size in marine Crustacea. Am. Nat. 106: 321-350.

Winkler D.W., Wallin K. 1987. Offspring size and number - a lifehistory model linking effort per offspring and total effort. Am. Nat. 129: 708-720.

Zar J.H. 2010. Biostatistical analysis. 5th edition. Upper Saddle River, NJ: Prentice-Hall.

Scient. ed.: J.A. Cuesta.

Received September 9, 2011. Accepted March 20, 2012.

Published online August 2, 2012. 